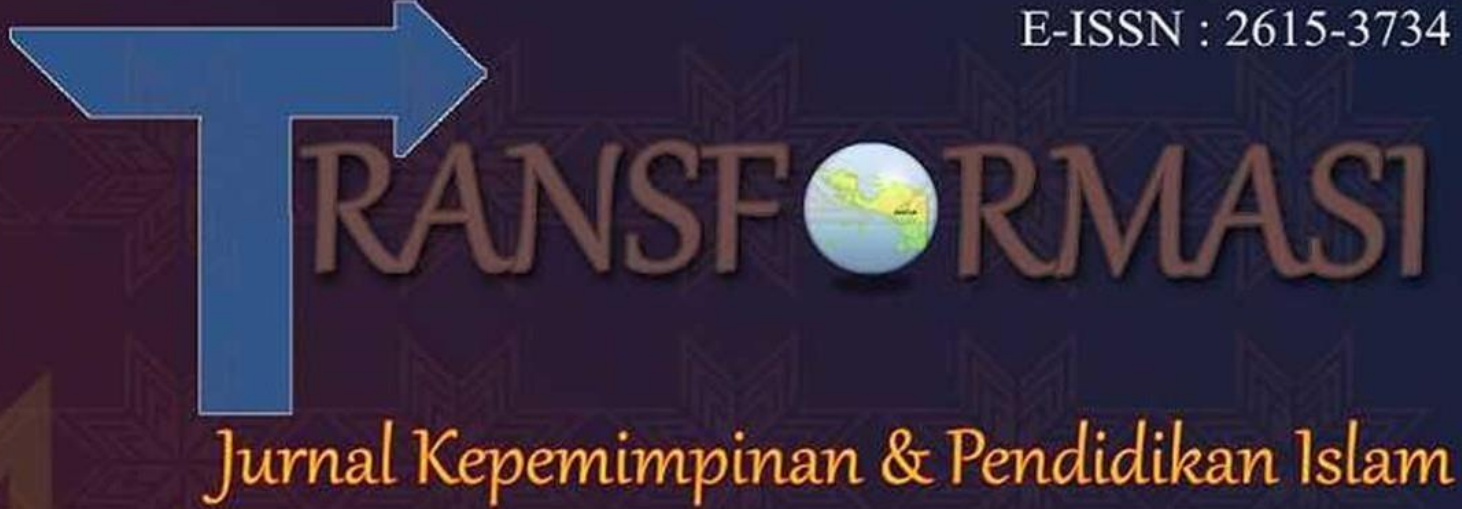

\section{VOLUME 5 NOMOR 1 DESEMBER 2021}

KEPALA SEKOLAH SEBAGAI PEMIMPIN (Leader) DALAM MENINGKATKAN PROFESIONALISME GURU DI MADRASAH TSANAWIYAH MUHAMMADIYAH 02 AIMAS KABUPATEN SORONG

\section{Khatipah Dan Hermanto}

SEJARAH PERKEMBANGAN PENDIDIKAN ISLAM DI DAERAH MINORITAS MUSLIM

Nazrul Fauzi Dan Asep Abdul Muhidin

IMPLEMENTASI MULTIPLE INTELLIGENCE FOR TEACHING PADA LEMBAGA PENDIDIKAN ISLAM TERPADU

DI KOTA SORONG PAPUA BARAT

Muhammad Adnan Firdaus

METODE EKLEKTIK DALAM PEMBELAJARAN BAHASA ARAB

\section{Azizul hakim}

EKSISTENSI BUDAYA LOKAL GORONTALO SEBAGAI IDENTITAS SUKU BANGSA DALAM DIMENSI GLOBALISASI DAN MODERNISME

Supriyanto Mohi

ANALISIS PERAN PADA ORANG TUA DALAM PEMBENTUKAN AKHLAK ANAK MILLENIAL DI SEKOLAH MADRASAH ALIYAH ALLU KECAMATAN BANGKALA KABUPATEN JENEPONTO

Hajrah 


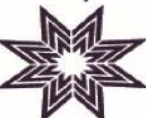

\title{
EKSISTENSI BUDAYA LOKAL GORONTALO SEBAGAI IDENTITAS SUKU BANGSA DALAM DIMENSI GLOBALISASI DAN MODERNISME
}

\section{Supriyanto Mohi, M.Pd}

Guru di SMP Negeri 1 Wanggarasi Kabupaten Pohuwato

Email: mohisupriyanto18@gmail.com

\begin{abstract}
Culture is an ethnic identity that needs to be maintained and preserved to become a source of wealth for the nation and state. Globalization and modern ideologies are presented to provide another space that can assimilate cultural values in each ethnic group, which is commonly referred to as local wisdom. This study aims to explore, study, and obtain descriptive information about Gorontalo local culture as ethnic identity in globalization and modernism dimension. The research method used is qualitative with a phenomenological approach. Data collection techniques were observation, interviews, literature studies, and documentation. The study's findings showed that the existence of the local culture of the Gorontalo people in the use of regional languages and Huyula culture, in general, has experienced quite a tremendous shift in values due to people's misinterpretation of current development through which globalization and modern ideology assimilated. Likewise, the transformation of cultural values through the role offormal, non-formal and informal education and other stakeholders was quite weak.
\end{abstract}

Keywords: Local Culture, Globalization, and Modernism 
TRANSFORMASI: Jurnal Kepemimpinan Dan Pendidikan Islam

Volume: 5 Nomor 1 Desember 2021

Eksistensi Budaya Lokal ...., H. 57-75

\section{Suprianto Mohi}

\section{PENDAHULUAN}

Indonesia adalah negara yang sering disebut 'tanah surga' karena anugerah kekayaan yang dimilikinya. Sebagai negara kepulauan yang terbentang luas dari Sabang sampai Merauke, maka secara geografis Indonesia memiliki kurang lebih 17.508 pulau-pulau besar dan kecil. Kondisi geografis yang demikian, menjadikan Indonesia sebagai negara yang ber-keberagaman dan bahkan dikenal oleh dunia sebagai negeri seribu budaya. Keberagaman budaya yang dimiliki oleh berbagai suku bangsa yang mendiami 34 Provinsi di Indonesia memiliki perbedaan dan keunikannya masing-masing baik dari segi bahasa, adat istiadat, kebiasaan, dan hal lainnya yang dianggap memiliki nilai moral-sosial dalam kehidupan masyarakat. Dan inilah yang kemudian disebut dengan 'budaya lokal' daerah.

Gorontalo merupakan salah satu wilayah adminstratif yang terletak di bagian timur Indonesia. Dalam hal budaya, Gorontalo memiliki khas tersendiri sebagai identitas daerah. Kekayaan budaya lokal yang dimiliki Gorontalo merupakan hasil warisan nenek moyang yang diwariskan secara turun-temurun dari setiap generasi ke generasi. Oleh karena itu, seiring dengan perkembangan zaman yang ditandai oleh perkembangan teknologi dan kemajuan sumber daya manusia, maka seyogianya kekayaan budaya tersebut dapat dikembangkan dan dilestarikan oleh setiap generasi. Namun nyatanya tidak demikian, justru perkembangan teknologi 'modern' baik transportasi, informasi dan komunikasi yang dimulai sejak abad ke-18 hingga abad ke-20 membuat harpan itu sirna.

Dewasa ini, kita menyadari bahwa pada beberapa daerah di Indonesia yang telah melalui fase-fase perubahan sosial dalam hal perkembangan dan kemajuan daerahnya, nampak signifikan dengan pergeseran nilai-nilai kebudayan lokal. Termasuk salah satu dari sekian pergeseran itu adalah budaya lokal sebagai identitas daerah Gorontalo. Nilai-nilai budaya 'kearifan lokal' daerah tinggalah menjadi slogan belaka bahkan eksistensinya nyaris hilang tidak berwujud. Begitulah yang ditemukan pada beberapa kondisi aktivitas dan kehidupan masyarakat, khususnya masyarakat lokal Gorontalo. Saat ini, budaya telah berada pada titik kulminasi dari tantangan kemajuan dan perkembangan zaman terhadap eksistensi nilai-nilai kebudayaan atau yang dikenal sebagai 'kearifan lokal' daerah. Kurang efektifnya cara atau metode 
TRANSFORMASI: Jurnal Kepemimpinan Dan Pendidikan Islam

Volume: 5 Nomor 1 Desember 2021

Eksistensi Budaya Lokal ...., H. 57-75

Suprianto Mohi

dalam men-transformasikan nilai-nilai budaya pada setiap generasi juga menjadi salah satu alasan mendasar. Akibatnya, resistensi yang terjadi berimplikasi pada pergeseran nilai sebagai hakikat budaya bangsa. Inilah yang menyebabkan mengapa budaya lokal sebagai identitas suku bangsa mulai nampat terbenam di ufuk globalisasi dan faham moderenitas.

\section{PEMBAHASAN}

\section{A. Gobalisasi dalam Dimensi Transkulturasi}

Globalisasi lahir dari sebuah faham modern atau lazim disebut dengan 'modernisme'. Globalisasi memiliki sifat multidimensi. Oleh karena itu, globalisasi merupakan bentuk penyatuan negara-negara pada dimensi kehidupan baik ekonomi, sosial, budaya, politik, teknologi dan sebagainya. Sehubungan dengan hal ini, Limas Sutanto (Gunawan dan Wulandari, 2015 : 150) mengartikan bahwa globalisasi adalah menyatunya dunia melalui kemudahan dalam akses teknologi informasi dan komunikasi. Pendapat ini menekankan bahwa kemajuan teknologi transportasi dan komunikasi subjektifnya memberikan dampak positif terhadap perkembangan wilayah, baik perkembangan teknologi maupun perkembangan dalam bidang ekonomi kerakyatan. Globalisasi dapat saja menjadi sarana yang lebih maju dalam mendorong kemajuan suatu daerah di bidang ekonomi.

Sementara itu, dalam beberapa dimensi lainya globalisasi dapat pula menimbulkan dampak negatif. Sebagaimana pada era milenium ketiga, globalisasi membawa perubahan-perubahan yang cukup signifikan dalam segala aspek kehidupan masyarakat modern. Arus perubahan terus mengalir cepat dan membawa dampak negatif yang cukup kompleks. Namun meski pun demikian, sebagai manusia yang lahir pada zaman tersebut tentu tidak dapat mengisolasi diri dari pengaruh negatif globalisasi yang didominasi oleh faham-faham modern dalam realitas kehidupan masyarakat. Sehubungan dengan hal ini, Thomas L. Friedman (Gunawan dan Wulandari, 2015 : 150) menegaskan bahwa globalisasi adalah fenomena yang muncul setelah terjadinya Perang Dingin, dan akibatnya tidak dapat dihindari oleh siapa pun.

Dalam dimensi kebudayaan, globalisasi menjadi sumber transkulturasi di Indonesia. Tanpa terkecuali terhadap keberadaan nilai-nilai budaya yang ada pada 
TRANSFORMASI: Jurnal Kepemimpinan Dan Pendidikan Islam

Volume: 5 Nomor 1 Desember 2021

Eksistensi Budaya Lokal ...., H. 57-75

Suprianto Mohi

masyarakat suku Gorontalo. Pluralitas budaya yang dibawa masuk bersama arus globalisasi, selain membawa hembusan angin positif bagi masyarakat suku Gorontalo, juga membawa kemunduran yang cukup signifikan terhadap esensi nilai kebudayaan yang dimilikinya. Sikap moral-sosial yang ditanamkan melalui simbolsimbol kebudayaan Gorontalo kian lama makin hilang. Hadirnya globalisasi menyeret masyarakat suku Gorontalo pada hegemoni budaya-budaya asing. Akibatnya, pluralitas budaya yang diperoleh berubah nilai, di mana tidak dijadikan sebagai sumber wawasan dan pengetahuan, pengembangan nilai-nilai baru dalam kebudayaan yang dimiliki dan atau mendorong terciptanya praktik solidaritas-sosial antarmanusia. Namun justru yang terjadi adalah pluralitas menggeser nilai-nilai luhur yang telah diwariskan oleh nenek moyang sebagai pegangan hidup berupa modalmoral-sosial masyarakat Gorontalo sendiri. Transkulturasi membuat suku Gorontalo kehilangan identitas budaya. Transkulturasi yang inkonstitusional secara struktur bahkan mulai terbangun pada sikap-perilaku-kebiasaan kalangan usia remaja (anak muda) sebagai penerus tongkat estafet pelestarian budaya Gorontalo itu sendiri.

Fenomena transkulturasi yang terjadi pada kalangan anak-anak muda di Gorontalo, yakni seperti gaya hidup yang konsumtif dan hedonis. Bukan hanya di wilayah perkotaan saja, akan tetapi hingga pada ruang-ruang kehidupan masyarakat di desa mulai ter-akses dalam mindset pengaruh transkulturasi tersebut. Dan demikian itu, membuat nilai sosio-kultur pada generasi kita tergadaikan. Gaya hidup dan pemikiran anak-anak remaja sangat rentan dan mudah terkontaminasi dengan budayabudaya asing yang tidak sejalan dengan nilai-nilai kebudayaan sebagai khitah dalam kehidupan masyarakat Gorontalo sejak zaman dahulu kala.

Gorontalo dikenal dengan sebutan Serambi Madinah di Indonesia. Selain Aceh yang meperloleh sebutan sebagai Serambi Makkah. Gorontalo memiliki penduduk yang mayoritas umat Muslim. Oleh karenanya, pada zaman dahulu masyarakat Gorontalo dikenal sangat religius. Ajaran Islam sangat mempengaruhi eksistensi budaya di Gorontalo. Sehinga keduanya memiliki hubungan nilai yang sangat erat. Namun, seiring dengan perkembangan zaman memasuki era globalisasi, pengetahuan tentang kebudayaan lokal Gorontalo menjadi enggan dipelajari oleh kalangan pemuda dan warisan leluhur ini pun mulai terlupakan. Akibatnya, 
TRANSFORMASI: Jurnal Kepemimpinan Dan Pendidikan Islam

Volume: 5 Nomor 1 Desember 2021

Eksistensi Budaya Lokal ...., H. 57-75

Suprianto Mohi

transkulturasi menggeser peradaban masyarakat suku Gorontalo yang dulunya dikenal berkebudayaan dan religius, sekarang menjadi hampir tidak berbudaya. Bahkan sangat miris ketika identitas daerah 'kearifan lokal' Gorontalo perlahan sirna dan telah banyak masyarakat yang lebih menggemari budaya asing dari pada budaya sendiri.

Identitas budaya yang mulai hilang di Gorontalo, menjadi bukti hegemoni budaya-budaya asing semakin melekat kuat dalam sendi-sendi kehidupan masyarakat pribumi. Model ini, dengan secara perlahan akan merubah paradigma dan berdampak pada perubahan-perubahan sosial masyarakat yang cenderung cinta pada budayabudaya asing. Selain itu contoh paling terkecil adalah hilangnya tradisi dan kebiasaan yang mengandung nilai moral-sosil dalam pelaksanaan segala hal yang berbaur adatistiadat. Misalnya, dalam hal perayaan pesta pernikahan penggunaan alat musik tradisional seperti gambusi (alat musik dipetik) yang di iringi dengan nyanyian syairsyair yang mengandung nilai moral kebudayaan, kini hampir tidak dapat di temukan lagi pada kehidupan masyarakat zaman sekarang. Pesta hajatan pernikahan saat ini, jika dipresentasekan rata-rata $\pm 95 \%$ cenderung mengandung unsur nilai kebudayaan. Pesta dan hajatan pada kehidupan zaman sekarang hampir rata-rata menggunakan dan meniru tata cara modern dengan gaya budaya-budaya asing.

Dewasa ini, masyarakat suku Gorontalo menjadi lebih konsumtif lebih suka terhadap produk-produk luar negeri dibandingkan produk lokal. Kopiah keranjang 'upiya karanji' sebagai ciri khas Gorontalo yang merupakan warisan leluhur, sekarang sudah sangat jarang dipakai bahkan diganti dengan peci gaya modern. Apalagi pada kalangan remaja nyaris tidak dipakai lagi. Sehubungan dengan beberapa hal di atas, Ngugi Wa Thiong'o seorang penulis asal Kenya (Anastasia, dkk, 2015: 323) menyebutkan bahwa perilaku dan budaya asing khsusunya Amerika menginginkan hancurnya tradisi dan bahasa pribumi melalui bom budaya terhadap rakyat dunia. Pendapat tersebut merupakan suatu desekripsi bahwa Gorontalo juga menjadi salah satu daerah yang menjadi korban bom budaya dari bangsa asing. Implikasi globalisasi yang transkulturasi menjadi alasan utama akses utama bergesernya nilai-nilai kebudayaan pada suku Gorontalo. 
TRANSFORMASI: Jurnal Kepemimpinan Dan Pendidikan Islam

Volume: 5 Nomor 1 Desember 2021

Eksistensi Budaya Lokal ...., H. 57-75

Suprianto Mohi

Dampak terburuk dari globalisasi dalam dimensi transkulturasi, yakni akibat kemajuan teknologi trasportasi, informasi dan komunikasi meningkatnya kasus-kasus kriminalitas dan kejahatan dengan cara-cara yang canggih seperti perampokan dengan gaya baru berupa pembobolan ATM dan internet banking, perdagangan wanita, pergaulan bebas, prostitusi online, miras dan maraknya peredaran narkoba hingga kelas Internasional. Hal ini merupakan contoh kejahatan yang lebih menakutkan yang diakibatkan oleh dampak globalisasi.

Perkembangan zaman tentu memaksa manusianya untuk mengikuti arus. Terlebih para generasi muda, akan berada pada posisi dilematis dalam mempertahankan eksistensi budaya dan tradisi Gorontalo sebagaimana keaslian yang diwariskan oleh para leluhur. Dalam menyikapi hal ini, tentu diperlukan gerakangerakan inovatif dan peran secara aktif oleh semua pihak baik pemuda, masyarakat, tokoh adat, pemuka-pemuka agama, pemerintah dan pemangku kepentingan lainnya dalam melakukan upaya penyelamatan terhadap nasib budaya Gorontalo dari cengkraman budaya-budaya asing. Dengan meng-edukasi masyarakat umum secara konsisten dan kontinu, maka akan memutus mata rantai dampak negatif dari transkulturasi terhadap budaya lokal. Globalisasi dan perkembangan zaman subjektifnya justru akan lebih memperkaya wawasan budaya secara global. Tanskulturasi akan lebih mengajarkan soal pentingnya nilai persatuan dan kesatuan bagi bangsa dan negara yang masyarakatnya terlahir majemuk. Dengan demikian, atas dasar komitmen masyarakat dalam ber-budaya, maka dapat dijamin bahwa eksistensi nilai-nilai budaya lokal khusunya budaya dan 'kearifan lokal' Gorontalo akan terus lestari dan berkembang positif seiring dengan kemajuan zaman.

\section{B. Perubahan Sosial dan Peradaban di Tengah Faham Moderenitas}

Modernitas merupakan fenomena perubahan sosial pada tatanan kehidupan masyarakat. Sebagai manusia yang memiliki hasrat untuk berkembang dan maju, maka secara sistem tidak dapat melepas diri dari konteks modernitas. Perubahan secara sturktur dan sistem sosio-kultur yang secara signifikan terjadi dalam kehidupan masyarakat merupakan pengejewantahan dari pengaruh transformasi nilai perubahan ke-arah moderenitas. 
TRANSFORMASI: Jurnal Kepemimpinan Dan Pendidikan Islam

Volume: 5 Nomor 1 Desember 2021

Eksistensi Budaya Lokal ...., H. 57-75

Suprianto Mohi

Dalam hal masalah perubahan sosial, Wilber Moor (Elly, dkk, 2016: 51) memberikan pandangan bahwa perubahan sosial merupakan perubahan masyarakat pada tatanan struktur sosial, pola perilaku, dan interaksi sosial. Pendapat tersebut cenderung menekankan bahwa perubahan sosial menjadi sesuatu hal yang tidak dapat terpisahkan dari perubahan kebudayaan. Sebab unsur-unsur perubahan di atas, menyangkut dengan segala aspek kehidupan manusia termasuk signifikan dengan unsur-unsur kebudayaan di dalamnya. Sedangkan moderenitas merupakan suatu faham yang hadir di tengah-tengah masyarakat kontemporer yang menjadi motor aktif perubahan pada tatanan kehidupan masyarakat.

Penemuan alat-alat teknologi yang canggih adalah ciri dari perubahan ke arah modern. Sebagaimana teknologi trasportasi yang mulai berkembang sejak meletusnya revolusi industri pada abad ke-18 dan juga perkembangan alat-alat komunikasi pada abad ke-20, seperti elektornik, computer, dan internet. Pada konteks ini, merubah model-model dan cara produksi dari tradisional ke arah modern. Kemajuan dalam bidang teknologi transportasi dan komunikasi ini, menjadi titik kulminasi dari pengaruh faham moderenitas terhadap struktur dan sistem kehidupan sosio-kultur masyarakat modern.

Arus moderenisasi membawa pengaruh dan perubahan besar bagi seluruh dunia termasuk Indonesia sendiri. Perubahan ini tentu bersifat relatif, yakni ada perubahan yang memberi dampak positif terhadap peradaban kehidupan masyarakat dan juga perubahan yang menjadikan eksistensi peradaban masyarakat ikut hanyut dalam arus perubahan tersebut. Oleh karena itu, berhubungan dengan hal ini menurut Elly, dkk (2016: 62) bahwa dalam menghadapi arus moderenisasi Indonesia diperhadapkan dengan dua kewajiban, yakni pada kondisi tertentu ditekan untuk dapat melestarikan warisan budaya bangsa, dan di lain pihak dituntut membangun masyarakat yang modern.

Uraian di atas, dapat kita maknai bahwa kehendak modernitas semestinya sebagai manifestasi kemajuan masyarakat yang bertipikal Indonesia atau berjati diri sesuai dengan nilai-nilai kebudayaan lokal masing-masing. Pada konteks perubahan sosial, modernitas memang membawa perubahan yang cukup signifikan dalam kehidupan masyarakat. Akan tetapi, perubahan yang dimaksud tentu harus di 
TRANSFORMASI: Jurnal Kepemimpinan Dan Pendidikan Islam

Volume: 5 Nomor 1 Desember 2021

Eksistensi Budaya Lokal ...., H. 57-75

Suprianto Mohi

sandarkan pada nilai-nilai luhur yang telah terwariskan sebagai wujud derajat kehormatan atas identitas yang dimiliki suatu suku bangsa. Sebagaimana pendapat Smith (Elly, dkk, 2016: 60) bahwa moderenisasi merupakan suatu kebijakan yang terencana yang bertujuan untuk mengubah masyarakat pada kehidupan ke-kinian yang bernilai lebih maju dalam derajat kehormatan tertentu. Pendapat ini cenderung pada upaya kebijaksanaan manusia dalam menjaga identitas suatu suku bangsa di tengah arus modernisasi yang terus menghantam eksistensi budaya. Perkembangan teknologi pada dasarnya mendorong kemajuan hidup manusia, tanpa melalaikan nilai-nilai luhur yang telah diwarsikan nenek moyang sebagai identitas yang dimiliki bangsa itu sendiri.

Pada hakikatnya, moderenitas mengandung konsekuensi 'logik' atas pemaknaan yang di-identikan pada suatu keadaan masyarakat yang kurang berkembang, ter-kebelakang, atau pun ter-tinggal. Modernitas lalu kemudian, mendorong kondisi keterbelakangan, ketertinggalan dan ketidak-majuan tersebut dapat lebih cepat mengejar perubahan pada kondisi yang lebih maju dan berkembang. Wibert E. Moore (1965:129) sebagaimana menegaskan bahwa pada dasarnya moderenitas merupakan bentuk transformasi nilai kehidupan secara total pada masyarakat tradisional menuju masyarakat yang lebih maju secara ekonomi dan politik sebagai mana pola-pola kehidupan yang dicirikan oleh negara-negara barat. Pendapat tersebut menekankan bahwa perkembangan manusia pada era kehidupan modern disamping mendorong manusia terlepas dari keterbelakangan dan ketertinggalan, namun di sisi lain pula bahwa modernisasi tidak dapat dihindarkan dari pengaruh hegemoni gaya kehidupan negara-negara barat yang bertentangan nilai dengan tradisi dan budaya suku bangsa yang dimiliki.

Menjadi masyarakat modern adalah hal yang wajar. Akan tetapi, yang dikehendaki adalah masyarakat modern yang beridentitas budaya lokal. Artinya, dengan modernisasi memungkinkan kita menjadi sederajat dengan bangsa lain yang telah maju, tetapi kita pun harus mampu dan tangguh dalam menghadapi tantangan arus modernisasi yang menyeret pada pola kehidupan yang bertentangan dengan nilai-nilai budaya lokal kita, sebagaimana yang telah diwariskan para leluhur. Budaya lokal pada dasarnya merupakan penafsiran nilai moral-sosial yang tumbuh 
TRANSFORMASI: Jurnal Kepemimpinan Dan Pendidikan Islam

Volume: 5 Nomor 1 Desember 2021

Eksistensi Budaya Lokal ...., H. 57-75

Suprianto Mohi

dan berkembang dalam kehidupan masyarakat tertentu. Implementasi nilai-nilai budaya tersebut menjadi bukti legitimasi masyarakat terhadap budaya yang dimiliki. Geertz (1992:5) menegaskan bahwa kebudayaan adalah pemaknaan dari simbolsimbol yang terwarisi secara historis, dan simbolik itu dijadikan sebagai sarana komunikasi, pelestarian dan pengembangan pengetahuan dan sikap dalam kehidupan.

Sementara itu, peradaban masyarakat dapat diukur pada pola kehidupan secara umum. Masyarakat modern hari ini, telah banyak mengingkari terhadap legitimasi kebudayaan sendiri. Di tengah faham-faham moderenitas yang muncul, membawa perubahan besar yang justru menggeser nilai-nilai kebudayaan. Implementasi nilai kebudayaan dan kearifan lokal di masing-masing daerah mulai pudar akibat hegemoni trend dan simbol-simbol modernitas. Termasuk nilai kearifan lokal pada masyarakat suku Gorontalo.

Nilai kearifan lokal masyarakat Gorontalo kali ini terbenam dalam fahamfaham modern atau yang dikenal dengan 'modernisme' masyarakat. Sebagai contoh paling terdekat adalah kearifan lokal masyarakat Gorontalo yang kian lama semakin bergeser nilainya bahkan menghilang. Sebagaimana budaya dalam berbahasa Mo Hulondalo dan budaya Mo Huyula. Demikian dua contoh tradisi dan budaya sebagai identitas masyarakat suku Gorontalo sebagai asset bangsa yang secara eksistensi terancam punah dipengaruhi oleh kemajuan zaman atau yang dikenal dengan modernisasi.

Pertama, Bahasa Gorontalo. Dari segi identitas bahasa, maka Gorontalo merupakan daerah yang menjunjung tinggi prinsip multikultural. Oleh karena itu, di Gorontalo sendiri bahasa daerahnya hidup berdampingan dengan bahasa Indonesia dan bahasa asing lainnya yang dimiliki daerah-daerah tetangga. Maka tentu, dalam hal melakukan interaksi sosial bahasa tersebut tidak dapat terhindarkan dari prinsip saling pengaruh-mempengaruhi. Pada kondisi ini, sebagai bentuk konsekuensi adalah bahasa yang dapat bertahan merupakan bahasa yang kuat, sedangkan yang keadaannya lemah akan semakin dipersempit ruang gerak kelestariannya.

Berbicara soal bahasa, Gorontalo dikenal sebagai daerah terunik. Sebab Gorontalo merupakan satu suku yang memiliki tiga bahasa, yakni bahasa Gorontalo, Bahasa Suwawa, dan Bahasa Atinggola. Akan tetapi bahasa utama yang digunakan 
TRANSFORMASI: Jurnal Kepemimpinan Dan Pendidikan Islam

Volume: 5 Nomor 1 Desember 2021

Eksistensi Budaya Lokal ...., H. 57-75

Suprianto Mohi

oleh mayoritas masyarakat Gorontalo adalah bahasa Gorontalo Asli. Sebagaimana dituliskan dalam Antologi Esay Remaja Gorontalo oleh Supriyadi (Anastasia, dkk, 2015: 231) bahwa dapat dipresentasikan 85\% bahasa Gorontalo digunakan oleh masyarakat pada umumnya, sedangkan bahasa Suwawa 'bune' digunakan sebagai bahasa sehari-hari khusus masyarakat Suwawa. Demikian pula dengan bahasa Atinggola, hanya menjadi bahasa sehari-hari masyarakat Kecamatan Atinggola. Sementara Kecamatan Suwawa dan Kecamatan Atinggola masing-masing hanya terdapat 5\% penduduk Gorontalo yang bermukim di daerah tersebut.

Penggunaan bahasa Gorontalo pada zaman dahulu merupakan bahasa yang cukup kental dan dipegang teguh sebagai bahasa sehari-hari mereka. Hal ini masih dapat kita buktikan bahwa di beberapa tempat dapat kita jumpai orang tua atau pun kakek kita ketika berinteraksi dengan orang se-usianya dapat dipasti mereka menggunakan bahasa daerah Gorontalo. Bahkan jika mereka diajak untuk berdialog dengan menggunakan bahasa Indonesia secara langsung, hampir mereka tidak dapat memahami arti dari bahasa Indonesia. Apalagi jika berbahasa Indonesia. Hal ini menunjukan bahwa betapa konsistenya mereka dalam menjaga nilai-nilai luhur kebudayaan lokal dalam kehidupan sehari-hari sebagaimana yang diwariskan oleh para leluhurnya.

Dewasa ini, bahasa Gorontalo sebagai salah satu aset daerah bahkan secara umum sebagai bagian dari kekayaan budaya bangsa Indonesia. Hari ini, ruang kelestariannya semakin sempit atau menuju pada posisi kepunahan. Padahal, bahasa merupakan alat yang cukup penting untuk digunakan manusia dalam melestarikan dan mengembangkan kebudayaan dan peradabannya. Secara sosiologis-antropologis seharusnya tiga bahasa yang dimiliki suku Gorontalo dapat dijadikan sebagai bahasa ibu atau bahasa pemersatu Gorontalo. Namun lagi dan lagi eksistensinya patut dipertanyakan. Bahasa sebagai identitas etnik, kini sudah sangat jarang digunakan oleh masyarakat. Bukan hanya pada kalangan orang dewasa, bahkan lebih miris lagi hingga pada kalangan generasi muda dan anak-anak sudah tidak dapat mengerti dan memahami apalagi berbahasa Gorontalo. Dan menjadi ironi jika budaya berbahasa daerah Gorontalo dianggap sebagai bahasa yang kuno dan ketinggalan zaman, sehingga membuat mereka malu jika berbahasa daerah Gorontalo. 
TRANSFORMASI: Jurnal Kepemimpinan Dan Pendidikan Islam

Volume: 5 Nomor 1 Desember 2021

Eksistensi Budaya Lokal ...., H. 57-75

Suprianto Mohi

Kedua, budaya Huyula. Kata Huyula merupakan suatu kata dalam bahasa daerah Gorontalo yang mengandung arti kerjasama, tolong-menolong atau gotongroyong yang didasarkan pada nilai solidaritas sosial. Tradisi ini merupakan kebiasaan masyarakat Gorontalo pada umumnya yang diwariskan secara turun-temurun pada setiap generasi. Kerjasama ini dilakukan sebagai upaya memenuhi kebutuhan sosial. Bentuk dan orientasi kerjasama yang dilakukan lebih pada kegiatan ekonomi, sosialbudaya dan keagamaan. Kegiatan tersebut sering dilekatkan pada suatu pendekatan nilai kekeluargaan dan kekerabatan.

Mochtar (Mohammad, 2005: 320) mengungkapkan bahwa Huyula adalah kebersamaan dalam membangun pernyataan dan sikap bijaksana yang diambil melalui musyawarah demi kepentingan dan kemaslahatan orang banyak. Berdasarakan pendapat tersebut, maka dapat disimpulkan bahwa Huyula merupakan sikap kebersamaan dan penyatuan presepsi dalam setiap musyawarah sebagai pondasi pembangunan masyarakat pada misi kepentingan bersama. Selain ungkapan di atas, masih dalam arti yang sama sebagaimana yang diungkapkan oleh Daulima (2004:82) bahwa Huyula adalah kegiatan melakukan pekerjaan secara bersama-sama atau berkelompok oleh anggota masyarakat dalam pengertian saling bahu-membahu yang dilakukan secara timbal-balik. Dengan demikian, Huyula menjadi suatu hal penting dalam kehidupan masyarakat sebagai wujud pebangunan karakter bangsa, khususnya bagi masyarakat suku Gorontalo. Huyula sebagai salah satu tradisi dalam kearifan lokal masyarakat Gorontalo yang menjadi identitas kesukuan Gorontalo. Demikian kiranya, identitas ini agar dapat dijaga dan dilestarikan seiring dengan perkembangan dan kemajuan zaman.

Rasid Yunus (2013: 68) mengungkapkan bahwa tradisi Gorontalo yang dikenal dengan budaya Huyula penerapannya dapat dilihat pada beberapa jenis kegiatan masyarakat, yaitu: 1) Ambu merupakan perkumpulan beberapa orang dalam melaksanakan suatu kegiatan yang memuat kepentingan bersama. Kegiatan ini dapat disebut dengan istilah kerja bakti, misalnya kegiatan dalam pembuatan jalan desa, tanggul desa, jembatan dan sebagainya. Dalam pengertian lain, Ambu juga dijadikan sebagai metode masyarakat dalam menyelesaikan suatu permasalahan, seperti 
TRANSFORMASI: Jurnal Kepemimpinan Dan Pendidikan Islam

Volume: 5 Nomor 1 Desember 2021

Eksistensi Budaya Lokal ...., H. 57-75

Suprianto Mohi

perkelahian antar warga; 2) Hileiya adalah salah satu kegiatan yang terjadi secara spontan menjadi suatu kewajiban dari setiap individu dan melibatkan banyak orang dalam hal bekerja sama memberi pertolongan pada suatu keluarga yang mengalami musibah, seperti musibah kedukaan; 3) Ti'ayo merupakan kegiatan tolong menolong yang dilakukan oleh sekelompok orang untuk menyelesaikan suatu pekerjaan milik seseorang. Sebagai contoh dari Ti'ayo adalah tolong menolong dalam kegiatan pertanian, kegiatan pembangunan rumah, kegiatan pembangunan 'bantayo' (tenda) dalam hajatan pernikahan dan lain sebagainya.

Berdasarkan uraian pendapat di atas, maka dapat dipahami bahwa kegiatan Huyula tersebut menjadi suatu tradisi yang telah dan pernah dipraktekan oleh para leluhur kita dalam membangun suatu karakter dan peradaban suku bangsa, khsusunya pada masyarakat suku Gorontalo. Budaya Huyula menjadi suatu tradisi yang diwarisakan leluhur sebagai modal solidaritas sosial yang menghubungkan setiap kepentingan manusia yang satu dan lainnya demi tercapainya tujuan yang memuat kepentingan baik secara individu maupun kepentingan bersama. Budaya Huyula dapat terukur pada komitmen masyarakat dalam mengimplementasikan nilai moralsosial pada tiga jenis kegiatan sebagaimana disebutkan di atas, yakni Ambu, Hileiya dan Ti'ayo.

Akan tetapi, karena kurang bijaknya masyarakat dalam menyambut hadirnya era modernitas menyebabkan budaya Huyula sedikit demi sedikit mulai hilang dari kebiasaan masyarakat suku Gorontalo. Moderenisme menjadi propaganda yang merobek nilai kepentingan bersama dan prinsip solidaritas masyarakat. Hal ini sangatlah nampak pada setiap perilaku dan aktivitas sosial mayarakat Gorontalo yang mulai mengabaikan warisan luhur budaya Huyula itu sendiri. Pada akhirnya, budaya ini mejadi hal yang sangat langka untuk dapat dijumpai pada setiap aktivitas masyarakat dan bahkan eksistensinya semakin termarginalkan. Hingga pada setiap generasi yang lahir, budaya ini semakin tidak dikenal apalagi untuk dilakukan. Kaitan dengan hal ini, Laliyo (Mohammad, 2005: 366-367) juga menjelaskan bahwa kehadiran globalisasi sebagai faham modern menyebabakan kearifan lokal Gorontalo semakin termarginalkan, kondisi ini nampak pada perilaku masyarakat yang mulai 
TRANSFORMASI: Jurnal Kepemimpinan Dan Pendidikan Islam

Volume: 5 Nomor 1 Desember 2021

Eksistensi Budaya Lokal ...., H. 57-75

Suprianto Mohi

abai terhadap budaya Huyula sebagaimana yang pernah dipraktekan oleh para leluhur terdahulu.

Berdasarkan hal tersebut di atas, kemunduran dari segi implementasi nilai budaya Huyula dapat kita amati secara langsung pada kondisi realitas sosial masyarakat modern hari ini. Nilai budaya, sebagaimana terkandung maksud dalam kegiatan Ambu pada kondisi masyarakat modern secara utuh, maka tidak dapat lagi diterapkan. Persaingan ekonomi pada era modern dan konsekuensi dalam mempertahankan hidup menjadi alasan utama masyarakat cenderung mengorientasikan jasa dan kinerja pada nilai materi bukan pada nilai sosial. Prinsip suka rela dalam bekerja menjadi hal yang sulit bahkan tidak mungkin dapat dilakukan lagi pada masyarakat modern. Misalnya, dalam pekerjaan jalan, tanggul dan jembatan, maka hari ini tidak lagi menjadi hal yang dapat dilakukan dengan metode dan pendekatan Ambu, karena program-program semacam ini sudah menjadi pekerjaan yang dilakukan dengan menggunakan bantuan alat teknologi modern. Sementara keterlibatan masyarakat pada pekerjaan semacam ini, digantikan dengan nilai uang sebagai upah hasil kerja. Kehadiran alat teknologi modern menjadi sumber utama keterbiasaan masyarakat cenderung menilai pekerjaan pada hal-hal materi ketimbang prinsip dan nilai moral-sosial-budaya.

Kemudian, menyangkut pengamatan pada prinsip nilai Huyula melalui kegiatan Hileiya. Pada masyarakat suku Gorontalo aktivitas tolong-menolong pada Hileiya sedikitnya masih ada dan dapat kita temukan pada masyarakat di wilayah pedesaan. Sementara di wilayah perkotaan nilai semacam ini sudah sangat sulit untuk ditemukan. Modernisme mebiasakan masyarakat untuk hidup berorientasi pada materi. Sebagaimana pada acara-acara kedukaan, keluarga justru cenderung dibebankan untuk mempersiapkan segala hal menyangkut materi untuk menyambut kehadiran tamu yang datang pada kedukaan. Misalnya, persiapan dan pengaturan tempat mengunakan tenda-tenda dan jasa yang harus berbayar dan beberapa hal lainnya. Hampir segala hal sifatnya berbayar dan menjadi beban tanggungan keluarga yang berduka. Demikian, halnya yang dapat kita temukan pada masyarakat di wilayah perkotaan. Sementara pada masyarakat di wilayah pedesaan, meskipun kegiatan semacam ini masih berwujud dan dapat ditemukan. Akan tetapi, pada generasi muda 
TRANSFORMASI: Jurnal Kepemimpinan Dan Pendidikan Islam

Volume: 5 Nomor 1 Desember 2021

Eksistensi Budaya Lokal ...., H. 57-75

Suprianto Mohi

dan anak-anak zaman sekarang nilai luhur ini tidak lagi tersalurkan atau diwarisi. Aktivitas generasi muda dan anak-anak zaman sekarang, mereka cenderung terhegemoni menikmati prodak-prodak modernisme. Mereka menjadi sibuk berpacu dengan gadget dan prodak-prodak modern lainnya. Sehingga abai dalam mencontoh nilai budaya dan kearifan yang diajarkan pada leluhur dan orang tua.

Di sisi lain, Ti'ayo sebagai suatu prinsip nilai pada era modern dengan perkembangan teknologi dan industri juga mendapat perlakuan yang sama di mata masyarakat suku Gorontalo. Cara dan metode ini tidak lagi dapat dipakai pada masyarakat yang telah menganut faham modern. Modernisme menghadirkan paradigma baru masyarakat yang cenderung mengunakan cara yang maju dengan difasilitasi alat teknologi yang serba canggih. Sebaliknya, pada zaman dahulu, sebagai contoh dalam hal pekerjaan di bidang pertanian dari tahapan pembukaan lahan, pembajakan, penanaman, penyiangan hingga panen seseorang masih dapat memakai cara Ti'ayo. Dengan Tia'ayo, mereka dapat bekerjasama melakukan kegiatan di bidang pertanian saling bahu-membahu secara bergilir menyelesaikan pekerjaan (kepentingan) setiap orang yang memiliki kepentingan yang sama. Begitu pula membangun rumah, dengan cara Ti'ayo tersebut rumah seseorang dapat diselesaikan secara gotong-royong oleh sekelompok masyarakat secara suka rela tanpa mengharapkan imbalan materi. Perilaku ini dilakukan secara bergilir pada setiap orang yang memiliki kepentingan yang sama. Akan tetapi, seiring dengan perkembangan zaman, masuknya modernisme melepaskan masyarakat dari pegangan prinsip Ti'ayo. Modernisme menghadirkan alat-alat canggih berbayar di tengahtengah masyarakat, baik di bidang pertanian maupun bidang sosial lainnya. Ironinya, yang terjadi adalah justru berbanding terbalik, di mana pekerjaan seseorang dari pembukaan lahan, pembajakan, penyiangan hingga panen dilakukan dengan mengunakan alat dan fasilitas modern yang dikendalikan jasa manusia secara berbayar. Begitu pula dengan kegiatan pembangunan rumah di arahkan pada caracara modern dengan jasa berbayar yang menghabiskan banyak biaya. Pada akhirnya, masyarakat terbiasa dengan keadaan ini dan nilai luhur kearifan lokal eksistensinya menjadi terabaikan. 
TRANSFORMASI: Jurnal Kepemimpinan Dan Pendidikan Islam

Volume: 5 Nomor 1 Desember 2021

Eksistensi Budaya Lokal ...., H. 57-75

\section{Transformasi Nilai Budaya Lokal}

Kuntowijoyo (2006: 56) mengungkapkan bahwa trasformasi adalah konsep pemindahan (trasmisi) suatu nilai budaya yang diyakini masyarakat tertentu kepada anak-anak sebagai generasi yang mewarisi nilai budaya dimaksud agar mereka lahir menjadi masyarakat yang memahami secara utuh nilai-nilai kebudayaan yang dimiliki. Pandangan ini, menekankan kepada setiap orang agar dapat memberi informasi keilmuan kepada setiap orang lainnya menyangkut esensi dan eksistensi nilai kebudayaan yang dimiliki, agar setiap individu masyarakat menjadikan nilai kebudayaan sebagai pondasi kehidupan sosial baik dalam bermasyarakat, berbangsa dan bernegara.

Perubahan sosial pada masyarakat dalam dimensi transformasi nilai menjadi hal yang wajar. Sebab trasformasi merupakan pergeseran kondisi suatu masyarakat pada sesuatu hal yang baru, tanpa merubah sedikit pun struktur nilai yang telah ada di dalamnya. Transformasi sejatinya menjaga eksistensi nilai budaya dan kearifal lokal masyarakat sebagai luhur bangsa yang tidak dapat dipisahkan dari dimensi kehidupan sosial. Capra (Pujileksono, 2009:143) berpendapat bahwa trasformasi memungkinkan adanya keterlibatan jaringan-jaringan hubungan sosial dan ekologis. Oleh sebab itu, apabila struktur jaringan tersebut berubah maka memungkinkan adanya pengaruh terhadap masyarakat secara kelembagaan. Nilai dan pemikiran masyarakat pula ikut berubah atau berevolusi. Peradaban dalam masyarakat yang menyangkut penanaman nilai-nilai kebudayaan bergantung pada peran trasformasi nilai kebudayaan itu sendiri pada setiap generasi dan masyarakat pada umumnya.

Berdasarkan uraian di atas, maka dapat disimpulkan bahwa trasformasi merupakan indikator utama yang perlu dilakukan dalam menjaga eksistensi nilai budaya dan kearifan lokal. Dengan konsep trasformasi, menjadikan kita sebagai masyarakat yang dimanis menjaga nilai budaya secara struktur, namun demikian juga akan terus maju dan berkembang mengikuti setiap perkembangan zaman. Menjadi hal yang paling penting adalah bagaimana efektifitas setiap lembaga dalam melakukan trasformasi nilai budaya kepada setiap individu masyarakat, dan terlebih kepada generasi muda dan anak-anak sebaga penerus tongkat estafet kebudayaan yang dimiliki oleh suatu suku bangsa. 
TRANSFORMASI: Jurnal Kepemimpinan Dan Pendidikan Islam

Volume: 5 Nomor 1 Desember 2021

Eksistensi Budaya Lokal ...., H. 57-75

Suprianto Mohi

Belakangan ini, jika kita mengamati dengan cermat maka dapat kita temukan bahwa trasformasi nilai-nilai kebudayaan terhadap generasi masih kurang optimal. Nyatanya, telah banyak generasi kita khususnya pada masyarakat suku Gorontalo yang tidak lagi memahami nilai-nilai kearifan lokal yang dimilikinya. Hal ini disebabkan karena peran-peran dalam mentrasformasikan nilai budaya, baik pada lembaga pendidikan formal, keluarga dan lingkungan sosial tidaklah berperan aktif. Padahal, anak-anak dan generasi muda seharusnya dipersiapkan sejak dini sebagai garda terdepan dalam pelestarian budaya. Membimbing dan membina generasi dapat dilakukan melalui tiga jenis pelayanan pendidikan sebagaimana di sebutkan di atas, yakni melalui pendidikan formal (lingkugan sekolah), informal (lingkungan keluarga), dan nonformal (lingkungan masyarakat) pada umumnya.

Pertama, lingkungan sekolah merupakan lembaga pendidikan formal yang sangat diharapkan mampu mengambil peran maksimal mendidik generasi dalam melestarikan nilai-nilai kebudayaan lokal. Pembelajaran muatan lokal di sekolah menjadi kurang efektif dilaksasnakan. Pelaksanaan beragam jensi lomba yang berbaur kebudayaan sebagaimana yang pernah dilakukan pada zaman dahulu, seperti lomba 'mohungguli' (bercerita dalam bahasa Gorontalo), pantun-pantun dalam bahasa Gorontalo dan tarian daerah secara tradisional cukup disayangkan hari ini tidak lagi dilaksanakan di sekolah-sekolah. Padahal, ini merupakan bagian dari upaya mentransformasi nilai dan menanamkan prinsip nilai kebudayaan pada anak-anak agar kelak menjadi pelopor peradaban melalui budaya suku bangsa.

Kedua, keluarga merupakan unsur paling terkecil yang dapat mengambil peranan yang sama dalam hal melakukan transformasi nilai kebudayaan pada anakanak sebagai generasi pelopor kebudayaan. Melalui pendekatan keluarga, maka di dalamnya terdapat peran orang tua dan saudara yang lebih memiliki hubungan dan kedekatan sosial yang cukup kental, maka tentu peran transformasi ini akan lebih efektif lagi. Akan tetapi, pada masyarakat suku Gorontalo sendiri, peran-peran ini mulai hilang. Mungkinkah, karena akibat kemajuan dan perkembangan zaman yang semakin menuntut peran dan kesibukan orang tua di luar rumah. Sehingga menyebabkan komunikasi dan interkasi dalam menanamkan nilai-nilai kebudayaan pada keluarga terputus dan jarang dilakukan bahkan nyaris hilang dalam keluarga. 
TRANSFORMASI: Jurnal Kepemimpinan Dan Pendidikan Islam

Volume: 5 Nomor 1 Desember 2021

Eksistensi Budaya Lokal ...., H. 57-75

Suprianto Mohi

Globalisasi dan modernisme telah menyeret jauh nilai kearifan lokal dari kehidupan masyarakat suku Gorontalo. Padahal keluarga menjadi salah satu ujung tombak pelestarian budaya yang paling efektif.

Ketiga, yakni lingkungan sosial. Komunikasi dalam lingkungan sosial yang cukup santai dan tidak mengikat, menjadi kelemahan utama masyarakat dalam melakukan transformasi nilai budaya dan kearifan lokal. Transkulturasi yang inkonsistensi mendahului peran transformasi dalam kehidupan masyarakat Gorontalo pada umumnya. Masuknya faham modernitas dan globalisasi ke dalam sendi-sendi kehidupan, membuat masyarakat menjadi senang mengadopsi gaya hidup atau lebih tepat disebut sebagai budaya-budaya baru yang tidak sejalan dengan sejatinya nilai luhur budaya yang dimiliki suku Gorontalo. Misalnya, dalam berinteraksi, banyak dijumpai penggunaan bahasa lain yang menjelma dalam bahasa masyarakat Gorontalo. Sebut saja itu adalah bahasa gaul yang lebih senang dipakai oleh anakanak jaman sekarang dalam berkomunikasi. Lagi dan lagi kearifan lokal Gorontalo menjadi terancam rapuh akibat lemahnya komitmen masyarakat dalam mewariskan dan membentengi generasi dengan nilai-nilai kebudayan yang sejati.

\section{KESIMPULAN}

Transkulturasi budaya yang dibawa masuk bersama pengaruh globalisasi menjadi tantangan berat bagi suku bangsa dalam mempertahankan eksistensi budaya dan kearifan lokal yang dimiliki. Segala pengaruh yang ditimbulkan bermuara pada peradaban budaya suku bangsa. Suku Gorontalo sendiri, menjadi satu dari sekian kesukuan di Indonesia yang menghadapi fenomena pergeseran nilai-nilai kebudayaannya. Memang, tidaklah dapat dipungkiri bahwa setiap manusia menghendaki perubahan dan kemajuan seiring dengan perkembangan zaman. Namun, hal yang terpenting sebagai cita-cita bangsa adalah menjadi masyarakat yang berkemajuan, tetapi dengan tidak mengabaikan identitas budaya dan kearifan lokal sebagai jati diri bangsa. Transkulturasi secara subjektif dapat dijadikan sebagai sumber ilmu pengetahuan yang dapat memperluas wawasan terhadap budaya di dunia dengan tidak merubah sedikit pun nilai secara struktur moral-sosial-budaya sebagai komitmen luhur yang telah diwariskan oleh para leluhur. 
TRANSFORMASI: Jurnal Kepemimpinan Dan Pendidikan Islam

Volume: 5 Nomor 1 Desember 2021

Eksistensi Budaya Lokal ...., H. 57-75

Suprianto Mohi

Di sisi lain, pun modernitas menjadi suatu faham dengan propaganda yang banyak melahirkan paradigma baru masyarakat. Paradigma yang lahir terbanyak inkonsistensi terhadap nilai-nilai kearifan lokal pada setiap daerah. Kemajuan dibidang teknologi informasi dan komunikasi menjadi bom budaya terhadap suatu suku bangsa, termasuk suku Gorontalo. Generasi muda sebagai pemegang tongkat estafet kelestarian budaya dan kearifan lokal Gorontalo menjadi sasaran utama inkonsistensi nilai dari faham modernitas. Pengabaian nilai-nilai budaya dan kearifan lokal Gorontalo terjadi karena esensi pemuda banyak terhegemoni dengan euforia menikmati prodak-prodak modern. Maka tidak dipungkiri jika kondisis tersebut menyebabkan pemahaman generasi terhadap identitas bangsa, yakni nilai-nilai budaya dan kearifan lokal sendiri menjadi berkurang. Akhrinya, segala aktivitas kehidupan selalu disandarkan pada nilai materi dan finansial dari pada nilai moral dan solidaritas sosial, sebagaimana budaya dalam berbahasa Hulondalo dan budaya Huyula dalam kearifan lokal masyarakat suku Gorontalo yang kian hari makin hilang dan terbenam di ufuk faham global dan modernitas.

Beberapa kasus diatas, kaitan dengan eksistensi nilai-nilai kebudayan merupakan implikasi dari lemahnya transformasi nilai pada masyarakat, terlebih pada anak-anak dan generasi muda. Padahal, mereka sebagai pemegang tongkat estafet kebudayaan yang berhak mewarisi nilai luhur tersebut dari para orang tua dan leluhur. Demikian juga peranan lembaga pendidikan formal, keluarga dan lingkungan sosial masih kurang maksimal dalam menyosialisasikan nilai-nilai kebudayaan dan kearifan lokal daerah. Penyelamatan nilai budaya dan kearifan lokal daerah ini dapat dilakukan manakala upaya dalam mentransformasi nilai kebudayaan pada setiap generasi dilakukan secara masif, terstruktur, dan terukur. Upaya ini membutuhkan peranan aktif dari lembaga pendidikan formal, informal dan juga nonformal. Dengan demikian maka eksistensi nilai budaya sebagai identitas suku bangsa, akan tetap terjaga dan selalu menyesuaikan, serta tetap pada keadaan-keadaan yang seimbang walau pun berada pada arus globalisasi dan modernisme. 
TRANSFORMASI: Jurnal Kepemimpinan Dan Pendidikan Islam

Volume: 5 Nomor 1 Desember 2021

Eksistensi Budaya Lokal ..., H. 57-75

\section{Daftar Pustaka}

Anastasia, H. A, dkk. 2015. Menjaga Nilai Tradisi Tolangga di Gorontalo. Gorontalo: Kantor Bahasa Provinsi Gorontalo.

Daulima, F. 2004. Aspek-Aspek Budaya Masyarakat Gorontalo. Banthayo Pobo'ide Limboto: Fitrah

Elly M. S, dkk. 2016. Ilmu Sosial Budaya Dasar. Edisi 3. Jakarta: Prenadamedia Group.

Geertz, C. 1992. Tafsir Kebudayaan (Refleksi Budaya).Yogyakarta: CANISIUS

Kuntowijoyo. 2006. Budaya dan Masyarakat (Edisi Paripurna). Yogyakarta: Tiara Wacana

Mohammad, F. et al. 2005. Menggagas Masa Depan Gorontalo. Yogyakarta: HPMIG Perss.

Pujileksono, S. 2009. Antropologi (Edisi Revisi). Malang: UMM Perss

Rasid, Y. 2013. Transformasi Nilai-Nilai Budaya Lokal Sebagai Upaya Pengembangan Karakter Bangsa. Jurnal Penelitian Pendidikan. Vol 14 (1) 67-68

Wibert, E. M. 1965. Sociale Verandering dalam Social Change. DIterjemahkan oleh A. Basoski, Prisma Boesken. Antwepen: Untrecht. 